\title{
Notes
}

\section{Outing, Privacy, and the First Amendment}

\author{
John P. Elwood
}

The neologists have been at it again. One of their recent contributions to popular discourse is the term "outing," used to describe not a picnic but, in the words of the new Webster's College Dictionary, "the intentional exposure of a secret homosexual."1 Once a tool of the Right Wing for harassing opponents, ${ }^{2}$ the exposure of prominent "closet" homosexuals has become a favorite tactic of gay, lesbian, and bisexual ${ }^{3}$ activists bent on achieving various political ends, including greater public acceptance of homosexuals, more sympathetic civil rights legislation, and increased funding for AIDS research. According to its advocates, outing serves three basic purposes: (1) to expose the illogic of governmental

1. WEBSTER's COLLEGE DICTIONARY 960 (1992). As used in this Note, the term "outing" denotes the imputation of homosexuality to a person, especially a public figure, by the media. The word "outing" derives from the concept of forcing one "out of the closet" (i.e., out of privacy) about one's homosexuality. An "out" homosexual admits to her sexual preferences. By the same logic, a "closet" or "closeted" homosexual does not. One can be "out of the closet" to two different audiences: (1) to oneself and other homosexuals and (2) to the public at large. See JOHN D'EMIIIO \& ESTELLE B. FREEDMAN, LNTIMATE MATTERS: A HISTORY OF SEXUALITY IN AMERICA 322 (1989). The latter sense is the focus of this Note.

2. Bill Turque et al., The Age of 'Outing,' NEwSWEEK, Aug. 12, 1991, at 22. Outing was used in the McCarthy era to silence opponents. D'ENIIIIO \& FREEDMAN, supra note 1, at 292-94. More recently, editors at The Dartmouth Review surreptitiously recorded a meeting of the Dartmouth Gay Students Association and published excerpts of participants' comments. BENJAMIN HART, POISONED IVY 249-50 (1984). The Review article named two of the organization's leaders but did not identify other participants. State Won't Press Dartmouth Case, N.Y. TMEs, Oct. 9, 1984, at A20.

3. Increasingly, the term "gay" does not encompass lesbians or bisexuals. Eve Kosofsy Sedgwick, EPISTEMOLOGY OF THE CLOSET 17-18 (1990). Critics believe that using the word as a gender-neutral term is insensitive to the unique experience of homosexual women. Adrienne Rich, Compulsory Heterosexuality and Lesbian Existence, in WOMEN-SEX AND SEXUALITY 62, 80-81 (Catharine R. Stimson \& Ethel Spector Person eds., 1980). However, for the sake of brevity, this Note will use the terms "gay" and "homosexual" interchangeably. 
policies that discriminate against homosexuals and of the hypocrisy of gay public officials who publicly support such policies; ${ }^{4}(2)$ to provide positive examples of gays, as role models to other gays and as ambassadors to mainstream America; ${ }^{5}$ and (3) to break down the stigma surrounding homosexuality by making it commonplace. ${ }^{6}$

In the past, outing stories were confined to the pages of gay community publications and supermarket tabloids, and these two sources remain the primary purveyors of such literature. ${ }^{7}$ However, a recent spate of outings involving prominent figures has focused national attention on the subject. ${ }^{8}$ As a result, several well-respected newspapers and magazines have devoted stories to the outing phenomenon; some have even reported specific allegations, including the names of targets. ${ }^{9}$ By reporting the allegations of tabloids and gay publications, the mainstream media itself effectively engages in - and furthers the purposes of ${ }^{10}$-outing. The longstanding journalistic taboo that has kept the

4. For example, the national gay periodical The Advocate published a story alleging that Department of Defense spokesman Pete Williams was gay in order to call attention to the purported hypocrisy of the Pentagon's policy of excluding homosexuals from the armed services. See Michelangelo Signorile, The Outing of Assistant Secretary of Defense Pete Williams, THE ADVOCATE, Aug. 27, 1991, at 34; William A. Henry III, To "Out" or Not to "Out," TIME, Aug. 19, 1991, at 17.

5. Gabriel Rotello, former editor of the defunct New York City gay magazine OutWeek, told the New York Times, "It's taken for granted that other minorities deserve to have role models, so why not gays?" Dirk Johnson, Privacy vs. the Pursuit of Gay Rights, N.Y. TMES, Mar. 27, 1990, at A21. Michelangelo Signorile, former features editor of OutWeek and an ardent outing advocate, explained, "[w]e're saying homosexuality is natural; it's normal ... [I]s [homosexuality] so horrible [that] we should hide it? How can we ever convince the public that homosexuality is normal unless we show the public who is gay?" Stephen Randall, PLAYBOY, Sept. 1990, at 20. See also Zoe Heller, Outed: The Campaign Hits the Superstars, THE INDEPENDENT ON SUNDAY (London), June 16, 1991, at 12.

6. Michelangelo Signorile argues that, just as tabloid coverage of Ingrid Bergman's out-of-wedlock pregnancy helped break down societal stigmas surrounding illegitimacy, outing will allow greater openness about homosexuality. Michelangelo Signorile, Address at Yale Law School Symposium, Outing: The Debate Over Forcing Lesbian and Gay Public Figures Out of the Closet (Dec. 4, 1991) [hereinafter Signorile, Yale Law School Address].

7. Outing is not an activity confined to the press. A group called "Outpost" plasters pictures of celebrities around Manhattan with captions such as "Dyke," "Fag," and "Absolutely Queer." Heller, supra note 5. Democratic Representative Barney Frank of Massachusetts, who is openly gay, threatened to name homosexual Republicans in Congress in reprisal for Republicans' insinuations that Democratic Representative (and thencandidate for Speaker of the House) Tom Foley was homosexual. William A. Henry III, Forcing Gays Out of the Closet, TIME, Jan. 29, 1990, at 67. Michael Petrelis, a gay activist in Washington, D.C., held a press conference in May 1990 on the Capitol steps in which he read a list of 12 members of Congress whom he alleged were homosexual. Charlotte Low Allen, The Word is "Outing": Conservatives and Gays, WasH. TIMES, Sept. 13, 1990, at E2.

8. USA Today made outing a "cover story" on May 7, 1990, a sure sign that popular culture had taken note of the phenomenon. See Craig Wilson, Forcing gay celebs out of the closet, USA TODAY, May 7, 1990, at $\mathrm{Dl}$.

9. The Washington Post, which does not print the names of outing targets, rather sanctimoniously identified those publications that do. The list included the Oakland Tribune, the Philadelphia Inquirer, and the Miami Herald. See Eleanor Randolph, The Media, at Odds Over 'Outing' of Gays, Wash. Post, July 13, 1990, at Cl. USA Today peppered its discussion of the phenomenon with the names of outing "victims." Wilson, supra note 8.

10. Or so argues George Will, who writes that "[t]he respectable press [has] develop[ed] a parasitic relationship with the reckless media, such as the supermarket tabloids ...." George F. Will, Privacy and Predators, WASH. POST, Aug. 15, 1991, at A21.

Some would argue that including the names of outing targets in this Note constitutes a form of outing. However, (1) the author makes no claims about the veracity of the allegations that these figures are 
press from reporting on the homosexuality of public figures is slowly eroding, ${ }^{11}$ setting the stage for further episodes of outing in the future. ${ }^{12}$

The controversy over outing began as an internal debate in gay communities over the appropriateness of means to gain public acceptance; it has since provoked a wide-ranging discussion of journalistic ethics in the mainstream media. ${ }^{13}$ Predictably, the controversy found its way into the courts. ${ }^{14}$ An "outing" today potentially entails more than a bad sunburn or a few bee stings; reporting sensitive information about a person's sexual preferences may result in legal liability. The "invasion of privacy" tort regulates what truthful facts about a person can be disclosed and consequently lies at the heart of the outing controversy. ${ }^{15}$ Courts have attempted to balance the privacy rights of individual

homosexual; (2) not using actual names would be a futile gesture, because all names mentioned here have appeared in several major newspapers or magazines; (3) the author believes that the educational value of having real-life examples outweighs the minuscule injury of having names repeated in this Note.

11. Rona Barrett, a prominent gossip columnist, once noted that "[h]omosexuality is the only subject still taboo in America." Linda Bird Francke et al., Gossip Mania, NEwswEEK, May 24, 1976, at 56, 64. More recently, a tabloid editor observed, "We're now treating gay liaisons with about the same nonchalance as we do heterosexual. What wasn't permissible [a] number of years ago is now permissable [sic]." Pat $H$. Broeske \& John M. Wilson, Outing Target Hollywood, L.A. TIMES, July 22, 1990, at F86 (quoting Richard Kaplan, Editor of the Star). Another gossip columnist has remarked that, though she was initially "shocked" by the outing trend, today "it's as legitimate to write about gay relationships as it is to write about Liz and Dick." Id. at F89 (quoting Janet Charlton of the Star).

12. Richard Rouilard, Editor-in-Chief of The Advocate, told the Los Angeles Times, "We're in favor of outing .... We're working on outing stories on right-wing politicians and Vatican officials." Beth Ann Krier, Media: Some Say the Practice of 'Outing' May Have Benefited Gay Rights, L.A. TMES, Dec. 31, 1990, at E2. Michelangelo Signorile, himself responsible for outing Malcolm Forbes and Pete Williams, displays no intention to curtail his efforts. See Signorile, Yale Law School Address, supra note 6. The National Enquirer boasts that it is "sitting on hundreds of names." Broeske \& Wilson, supra note 11, at F90 (quoting an anonymous source at the Enquirer).

13. See, e.g., Randolph, supra note 9; Turque et al., supra note 2, at 23; Will, supra note 10.

14. Just last year, actor Tom Selleck sued the tabloid the Globe for $\$ 20$ million, claiming that the newspaper had libeled him by reprinting allegations made in a poster campaign that he was homosexual. The parties settled the suit prior to trial. See Mark Lundgren, Personals, S.F. CHRON., Aug. 16, 1991, at E3; Outing Lawsuit Resolved, THE INDEPENDENT, Aug. 6, 1991, at 9. Less than two weeks later, the Globe printed an article entitled, "Macho Newlywed Lyle Alzado Is Dying . . . and Male Hookers Say NFL Hunk Is Secret Gay." The former professional football player sued for defamation. See Milt Policzer, Novel Defense: No Stigma = No Libel, NAT'L L.J., Sept. 9, 1991, at 6.

15. The tort of defamation is also implicated by outing incidents, but whereas the privacy tort concerns truhful disclosures, defamation concerns false statements of fact which injure a person's reputation (truth is a complete defense to a defamation action). This Note does not discuss defamation except as it is relevant to the privacy tort. This is not because of a naive belief that "in the typical outing case, the allegations ... are true." Ronald F. Wick, Note, Out of the Closet and Into the Headlines: "Outing" and the Private Facts Tort, 80 GEO. L.J. 413, 415 (1991). The nature of sexuality is such that, short of a public declaration, one can never be sure of another's preferences. Instead, this Note focuses on the privacy tort because the current law of defamation is adequate to handle cases in which the allegations are patently false. See infra note 148 and accompanying text. Novel legal issues arise when the allegations are, at least in some part, true, because it is then that naming names has the potential to suppress unpopular viewpoints.

A person's sexual preference is an inherently slippery matter, not amenable to ready observation or proof while at the same time a favorite topic of idle speculation. With such great potential for error, it is not surprising that the vast majority of lawsuits involving the imputation of homosexuality are actions for defamation, not for invasion of privacy. Plaintiffs may choose to sue for defamation (1) because they actually are heterosexual, (2) because they do not wish to admit their homosexuality by bringing a privacy action, or simply (3) because of a perception that the chances for recovery of damages are slightly better in actions for defamation. For a discussion of the implications of outing on the tort of defamation, see Jon E. Grant, Note, "Outing" and Freedom of the Press: Sexual Orientation's Challenge to the Supreme Court's Categorical 
plaintiffs against societal rights of free speech. In so doing, the judiciary has developed intricate rules for recovery of damages in such tort actions.

This Note examines whether current privacy law adequately balances individual and societal rights, and finds that it does not. Courts fail to recognize the full scope of interests protected by privacy rights. As a consequence, when privacy rights come into conflict with First Amendment interests, however slight, courts favor the latter. The privacy tort survives at the fringes of the law, eviscerated by a "newsworthiness" standard that systematically overprotects speech at the expense of privacy rights and accords full First Amendment protection to the disclosure of celebrities' slightest peccadillos. ${ }^{16}$ Closer examination of the interests advanced by privacy rights, aided by analysis of the outing experience, demonstrates the need for a new balance. This Note argues for a revised standard of newsworthiness that would be sensitive to the nature of the information involved, and under which disclosure of a public figure's homosexuality would have to be relevant to a matter of legitimate public concern to be privileged under the First Amendment. ${ }^{17}$

Part I outlines the current contours of the invasion of privacy tort. Part II examines the importance of privacy, as demonstrated by the outing phenomenon. Part III discusses when disclosure of a public figure's homosexuality is protected by the First Amendment, and proposes a new standard for determining newsworthiness.

Jurisprudence, 77 CORNELL L. REV. 103, 121-27 (1991).

The torts of defamation and invasion of privacy are designed to remedy distinct types of harms. Defamation concerns injury done to an individual's reputation, which "lower[s] him in the estimation of his fellows"; the wrong involved in defamation is "material, rather than spiritual." Samuel D. Warren \& Louis D. Brandeis, The Right to Privacy, 4 HaRV. L. REV. 193, 197 (1890). The gravamen of a privacy action is invasion of the right to "an inviolate personality," id. at 205 , which courts have interpreted to mean infringing an individual's independence, dignity, and integrity. Emotional distress may be one result. See Edward J. Bloustein, Privacy as an Aspect of Human Dignity: An Answer to Dean Prosser, 39 N.Y.U. L. REV. 962,970 (1964). The law of defamation is relevant to the outing debate because it also seeks to balance common law tort rights and constitutional rights to free speech. See, e.g., New York Times v. Sullivan, 376 U.S. 254 (1964).

16. Dorsey D. Ellis, Jr., Damages and the Privacy Tort: Sketching a "Legal Profile," 64 IowA L. REv. $1111,1133-34$ (1979).

17. Some may argue that the Supreme Court's recent decision in RA.V. v. City of St. Paul, Minnesota, 112 S. Ct. 2538 (1992), precludes judicial recognition of a cause of action encompassing outing. In R.A.V., the Court struck down a St. Paul municipal ordinance outlawing the placement of "symbol[s] ... which ... arouse[] anger, alarm or resentment in others on the basis of race, color, creed, religion or gender" as facially unconstitutional under the First Amendment. Id. at 2541, 2547. The statute at issue in R.A.V. bears a superficial resemblance to the privacy tort, in that both would penalize potentially inflammatory speech relating to membership in a minority. However, a fortified privacy tort, like that suggested in this Note, does not necessarily implicate the concems animating the Court in R.A.V.. The Court was not troubled by the regulation of speech based on content (here, "fighting words"). Id. at 2543. Instead, the Court found the St. Paul statute invalid because it regulated speech based on whether it came within one of the disfavored categories, speech "that communicate[s] messages of racial, gender, or religious intolerance." Id. at 2549. As Justice Stevens explained, the majority believed the statute "regulate[d] expression based on viewpoint." Id. at 2570 (Stevens, J., concurring). However, the privacy tort advanced in this Note is viewpoint-neutral. The cause of action would be available regardless of the political views of the outer. Furthermore, the cause of action would be available not only in outing cases, but in all cases involving the disclosure of exceptionally private information. 


\section{InVasion of Privacy by PUblic Disclosure of PRIVATe Facts}

"There's no such thing as privacy rights .... That's just something the Supreme Court said. It's nowhere in the Constitution." ${ }^{\text {"18 }}$

These are not the words of Robert Bork, although they could be. ${ }^{19}$ The quoted speaker is instead gay activist Michelangelo Signorile. Signorile is right on one count: privacy rights appear nowhere in the text of the constitution. But he is wrong on another count: there is such a thing as a right to privacy, which is alive (if not entirely well) in the common law of the states.

Blanket use of the term "the right to privacy" generates confusion among both laypersons and lawyers. The constitutional "right to privacy"- the bane of Professor Bork-encompasses two distinct varieties of interests. One type "is the individual interest in avoiding disclosure of personal matters" by the government. ${ }^{20}$ The second type is "the interest in independence in making certain kinds of important decisions," involving "matters relating to marriage, procreation, contraception, family relationships, and child rearing and education."21 The two interests are commonly referred to as the "confidentiality" and "autonomy" interests, respectively. ${ }^{22}$

The right discussed in this Note is the common law, tort-based right of privacy, which is enforceable against private parties such as the media. Constitutional privacy, on the other hand, is enforceable against the government. While the underlying interest in inviolate personality is the same for both the constitutional and tort actions, the difference between state and nonstate action is constitutionally significant because common conceptions of appropriate behavior for private persons and government officials are different. ${ }^{23}$

18. Allen, supra note 7, at E2 (quoting Michelangelo Signorile).

19. See ROBERT H. BORK, THE TEMPTING OF AMERICA: THE POLITICAL SEDUCTION OF THE LAW 97, 113 (1990) (criticizing Justice Douglas' opinion in Griswold v. Connecticut, 381 U.S. 479 (1965)).

20. Fraternal Order of Police, Lodge No. 5 v. City of Phila., 812 F.2d 105, 109 (3d Cir. 1987) (quoting Whalen v. Roe, 429 U.S. 589, 599-600 (1977)).

21. Barry v. City of New York, 712 F.2d 1554, 1558-59 (2d Cir.) (citations omitted), cert. denied, 464 U.S. 1017 (1983).

22. Id. It is the autonomy interest in privacy that is at the center of the abortion controversy. The autonomy interest is also at stake in sodomy cases. In 1986, the Supreme Court held that the right of privacy did not apply to consensual homosexual activity and thus that states were free to outlaw sodomy. See Bowers v. Hardwick, 478 U.S. 186, reh'g denied, 478 U.S. 1039 (1986). The Court held that the privacy right was restricted to matters of "family, marriage, or procreation," and not to sodomy. Id. at 190-91. However, that holding should be read narrowly, as applying only to the autonomy interest in privacy, and not to the confidentiality interest. The confidentiality interest in privacy is evidently much broader than the autonomy interest, extending to other personal matters such as finances. Compare Plante v. Gonzalez, 575 F.2d 1119, 1132 (5th Cir.) (holding that autonomy interest does not cover "financial privacy"), reh' $g$ denied, $580 \mathrm{~F} .2 \mathrm{~d}$ 1052 (5th Cir. 1978) with Fraternal Order of Police, 812 F.2d at 115 (holding that certain financial information "is entitled to privacy protection").

23. See, e.g., Bivens v. Six Unknown Named Agents of Fed. Bureau of Narcotics, 403 U.S. 388, 391-92 (1971) (rejecting respondents' efforts "to treat the relationship between a citizen and a federal agent unconstitutionally exercising his authority as no different from the relationship between two private citizens"). 


\section{A. Development of the Public Disclosure Tort}

In 1890, as a reaction to the perceived excesses of "yellow journalism," Samuel Warren and Louis Brandeis published The Right to Privacy, an article arguing that such a right was implicit in the common law. ${ }^{24}$ The authors noted that the law had gradually expanded its protection of the individual from property and person to include reputation and emotional well-being. ${ }^{25}$ Analyzing various judicial decisions, they detected the presence of an implied right of privacy, and argued that violation of such a right should give rise to a distinct cause of action. $^{26}$

Courts and legislatures were slow to accept the tort, and it developed erratically. After the New York Court of Appeals refused to recognize a cause of action for invasion of privacy, ${ }^{27}$ the New York legislature created one in $1903{ }^{28}$ The Georgia Supreme Court allowed a cause of action for a man whose name and picture were used in connection with a spurious advertising testimonial. ${ }^{29}$ Kansas recognized a similar cause of action in $1918 ;{ }^{30}$ Kentucky followed suit in 1927.31

For most of this century, judicial opinion strongly favored individual rights to privacy over the media's reporting interest. ${ }^{32}$ The famous case of Melvin v. Reid $^{33}$ involved a former prostitute who was tried for murder and acquitted, later marrying and resuming life as an average citizen. She brought suit against a filmmaker who, seven years later, released a movie based on her life, using

24. Warren \& Brandeis, supra note 15 .

25. Id. at 194-95.

26. Id. at $195-98$.

27. Roberson v. Rochester Folding Box Co., 64 N.E. 442 (N.Y. 1902) (conceming use of plaintiff's picture to advertise flour without her consent). Prior to this decision, lower courts had accepted the existence of privacy rights. The first case to allow recovery on the independent basis of the right of privacy enjoined a defendant from publishing a picture of an actress wearing tights. W. PAGE KEETON ET AL., PROSSER AND KEETON ON THE LAW OF TORTS $\$ 117$, at $850 \mathrm{n} .10$ (5th ed. 1984).

28. N.Y. CIV. RIGHTS LAW $\$ 50$ (McKinney 1992). However, the New York provision was a narrow reaction to the Roberson case, merely making unlawful the use of "the name, portrait or picture of any living person" for the "purposes of trade." Id. The statute does not encompass the public disclosure of private facts. See Freihofer v. Hearst Corp., 480 N.E.2d 349, 353 (N.Y. 1985).

29. Pavesich v. New England Life Ins. Co., 50 S.E. 68, 81 (Ga. 1905).

30. Kunz v. Allen, 172 P. 532 (Kan. 1918).

31. Brents v. Morgan, 299 S.W. 967,971 (Ky. 1927) (holding public posting of notice of overdue account to be invasion of privacy).

32. See Cox Broadcasting Corp. v. Cohn, 420 U.S. 469, 488 (1975) ("[T]he century has experienced a strong tide running in favor of the so-called right of privacy."). Examples of judicial concem for privacy rights abound. See, e.g., Mau v. Rio Grande Oil, Inc., 28 F. Supp. 845 (N.D. Cal. 1939) (holding that use of victim's name in radio dramatization of crime created cause of action for invasion of privacy); Daily Times Democrat v. Graham, 162 So. 2d 474 (Ala. 1964) (unauthorized use of photograph depicting woman at county fair whose dress had blown up); Reed v. Real Detective Publishing Co., 162 P.2d 133, 139 (Ariz. 1945) (unauthorized use of photo accompanying magazine story on a crime); Gill v. Hearst Publishing Co., 253 P.2d 441 (Cal. 1953) (publication of photo); Bazemore v. Savannah Hosp., 155 S.E. 194 (Ga. 1930) (unauthorized publication of photograph of malformed child); Trammel v. Citizens News Co., 148 S.W.2d 708 (Ky. 1941) (newspaper publication of payment overdue notice); Binns v. Vitagraph Co. of Am., 103 N.E. 1108 (N.Y. 1913) (use of likeness in a film).

33. 297 P. 91 (Cal. Dist. Ct. App. 1931). 
her actual name. ${ }^{34}$ The court held that, absent the use of her name, the film would have been protected because the public had a right to know the details of the trial, which were a matter of public record; however, the use of the plaintiff's name was not itself "justified," and thus fell outside the public's need to know. ${ }^{35}$ Barber $v$. Time, Inc. ${ }^{36}$ concerned the publication of a magazine article discussing one woman's rare eating disorder. The story featured her photograph above the caption, "Insatiable-Eater Barber . . . She eats for ten." The court held the publication to be actionable, commenting, "[w]hile plaintiff's ailment may have been a matter of some public interest because unusual, certainly the identity of the person who suffered this ailment was not."38

The plaintiff in Sidis v. F-R Publishing Corp.$^{39}$ did not fare as well. Sidis involved a faded former child prodigy who, having hoped to live his adult life in obscurity, sued after a magazine article reported on his eccentricities in graphic detail. Although the Sidis court recognized that "[r]evelations may be so intimate and so unwarranted in view of the victim's position as to outrage the community's notions of decency," ${ }^{, 40}$ it affirmed the dismissal of his suit. The court recognized newsworthiness as a limitation on the public disclosure tort, reasoning that "at some point the public interest in obtaining information becomes dominant over the individual's desire for privacy."41

Incorporation into the first Restatement of Torts helped popularize the tort, aided its development, and promoted standardization between states. ${ }^{42}$ Eventually, William Prosser distilled the tort of invasion of privacy into four distinct causes of action, one of which is the public disclosure of private facts. ${ }^{43}$ Today, thirty-eight states and the District of Columbia recognize the public disclosure of private facts tort. ${ }^{44}$ The most common form of the tort sets forth

34. Id. at 91 .

35. Id. at 93 .

36. 159 S.W.2d 291 (Mo. 1942).

37. Id. at 293.

38. Id. at 295 .

39. 113 F.2d 806 (2d Cir.), cert. denied, 311 U.S. 711 (1940).

40. Id. at 809 . The Sidis court was the first of many to make such an acknowledgement while denying recovery to the plaintiff. See, e.g., Time, Inc. v. Hill, 385 U.S. 374, 383 n.7 (1967).

41. Sidis, 113 F.2d at 809.

42. RESTATEMENT OF TORTS $\$ 867$ (1939); KEETON ET AL., supra note 27 , $\$ 117$, at 851.

43. William L. Prosser, Privacy, 48 CAL. L. REV. 383, 389 (1960). The four causes of action are (1) appropriation of plaintiff's name or likeness for the defendant's advantage, (2) unreasonable intrusion into plaintiff's solitude, "seclusion," or "private affairs," (3) public disclosure of private facts, and (4) publicity that places plaintiff in a false light. See generally KEETON ET AL., supra note 27, § 117, at 851-66 (outlining four causes of action and relevant caselaw). Not everyone agrees with Prosser's four-part formulation of the tort. One commentator has argued that Prosser's conception of the tort "repudiate[d] Warren and Brandeis by suggesting that privacy is not an independent value at all but rather a composite of the interests in reputation, emotional tranquility and intangible property." Bloustein, supra note 15 , at 962 . Others have noted that the core of Warren and Brandeis' tort is the public disclosure of private facts, and that the other three causes of action are "scions of meretricious liaisons between privacy and the torts of trespass, defamation, and passing-off or trade-mark infringement." Ellis, supra note 16, at 1111.

44. Steven I. Katz, Comment, Unauthorized Biographies and Other "Books of Revelations," 36 UCLA L. REV. 815, 819-20 (1989). Five states (Alaska, Delaware, Kentucky, Montana, and Wyoming) have yet to recognize the public disclosure tort. Seven states (Minnesota, Nebraska, New York, North Carolina, North 
four requirements of a cause of action for public disclosure of private facts: (1) public disclosure; (2) of private facts; (3) concerning a matter which would be highly offensive and objectionable to a reasonable person; and (4) which is not of legitimate concern to the public. ${ }^{45}$ Unlike the tort of defamation, truth is no defense. ${ }^{46}$

\section{B. The Public Disclosure Tort, Newsworthiness, and the First Amendment}

A tort based on the publication of truthful information is necessarily bounded by the First Amendment. The public disclosure tort internalizes free speech concerns in the form of the common law "newsworthiness" test, which is coextensive with First Amendment protections. ${ }^{47}$ This test limits liability to statements that are not "newsworthy"- -that is, not of legitimate concern to the public. ${ }^{48}$ Thus, a finding that a statement is "newsworthy" is a complete defense to the public disclosure tort. ${ }^{49}$ Newsworthiness is a conclusion reached by weighing the competing interests of the public's "right to know" against the individual's right to keep private facts from the public's gaze. ${ }^{50} \mathrm{~A}$ judge may determine that a particular publication was newsworthy as a matter of law; otherwise, newsworthiness is a question of fact for the jury. ${ }^{51}$ The Restatement

Dakota, Oregon, and Virginia) have expressly refused to recognize the public disclosure tort. Id. at $820 \mathrm{n} .20$. Some recognize the private facts tort by statute, others recognize it in caselaw. See generally LIBEL DEFENSE RESOURCE CENTER, 50-STATE SURVEY 1990-91: CURRENT DEVELOPMENTS IN MEDIA LIBEL AND INVASION OF PRIVACY LAW (8th ed. 1990-91) [hereinafter LDRC SURVEY] (citing and discussing each state's law).

45. The Restatement (Second) of Torts defines the public disclosure tort in the following manner: One who gives publicity to a matter concerning the private life of another is subject to liability to the other for invasion of his privacy, if the matter publicized is of a kind that

(a) would be highly offensive to a reasonable person, and

(b) is not of legitimate concern to the public.

RESTATEMENT (SECOND) OF TORTS \& 652D (1977). The requirements vary slightly from state to state.

46. See, e.g., Barker v. Huang, 610 A.2d 1341, 1350 (Del. 1992).

47. See Ross v. Midwest Communications, Inc., 870 F.2d 271, 274 (5th Cir.) ("[T] he constitution bar[s] liability for the dissemination of true, private information if no liability would exist under the common law tort."), cert. denied, 493 U.S. 935 (1989). See also RESTATEMENT (SECOND) OF TORTs § 652D, cmt. d (1977) ("When the subject-matter of the publicity is of legitimate public concern, there is no invasion of privacy. This has now become a rule not just of the common law of torts, but of the Federal Constitution as well."). Time, Inc. v. Hill also emphasized the relevance of "legitimate public concern" in determining whether First Amendment protection extended to a particular disclosure of information: "Freedom of discussion, if it would fulfill its historic function in this nation, must embrace all issues about which information is needed or appropriate to enable the members of society to cope with the exigencies of their period." 385 U.S. 374, 388 (1967) (quoting Thornhill v. Alabama, 310 U.S. 88, 102 (1940)).

48. See RESTATEMENT (SECOND) OF TORTS § 652D, cmt. h (1977).

49. Romaine v. Kallinger, 537 A.2d 284, 293 (N.J. 1988); Wick, supra note 15, at 425 . A judge may determine as a matter of law that a statement does not constitute "morbid and sensational prying" and thus is newsworthy under the Restatement standard. See infra text accompanying note 53. If so, the defendant will prevail. Otherwise, the jury (or other finder of fact) will determine newsworthiness. Wick, supra note 15 , at 425 .

50. Diaz v. Oakland Tribune, Inc., 188 Cal. Rptr. 762, 771 (Ct. App. 1983).

51. See id. at 772-73. 
articulation of the newsworthiness test, which has enjoyed widespread popularity in the courts, ${ }^{52}$ states that:

In determining what is a matter of legitimate public interest, account must be taken of the customs and conventions of the community; and in the last analysis what is proper becomes a matter of the community mores. The line is to be drawn when the publicity ceases to be the giving of information to which the public is entitled, and becomes a morbid and sensational prying into private lives for its own sake, with which a reasonable member of the public, with decent standards, would say that he had no concern. ${ }^{53}$

Some argue that because the media's vocation is to determine what is newsworthy and what is not, anything that is published is newsworthy. This view mistakenly equates public interest with the "public's appetite," and its adoption would eliminate the public disclosure tort altogether. ${ }^{55}$

The category of newsworthy information has undergone a steady expansion since the early 1950's, as courts have become increasingly solicitous of free speech $^{56}$ and increasingly reluctant to, in the words of one court, "sit as censors." 57 Disclosures are most intrusive when they clearly identify, by name, the persons involved. Courts once were willing to grant recovery when an otherwise newsworthy publication revealed the name of the plaintiff because "identification of the actor" associated with an embarrassing revelation "serve[d] little independent public purpose." $" 58$ But this was the era when names were

52. See, e.g., Gilbert v. Medical Economics Co., 665 F.2d 305, 307-08 (10th Cir. 1981); Virgil v. Time, Inc., 527 F.2d 1122, 1130 (9th Cir. 1975), cert. denied, 425 U.S. 998 (1976); Times Mirror Co. v. Superior Court, 244 Cal. Rptr. 556, 566 (Ct. App. 1988), cert. dismissed sub nom Times Mirror Co. v. Doe, 489 U.S. 1094 (1989); Goodrich v. Waterbury Republican-American, 448 A.2d 1317, 1331 (Conn. 1982); Howard v. Des Moines Register \& Tribune Co., 283 N.W.2d 289, 302 (Iowa 1979), cert. denied, 445 U.S. 904 (1980); Romaine v. Kallinger, 537 A.2d at 293-94; Hall v. Post, 372 S.E.2d 711, 714 (N.C. 1988).

53. RESTATEMENT (SECOND) OF TORTS $\$ 652 \mathrm{D}$, cmt. h (1977); see also Linda N. Woito \& Patrick McNulty, The Privacy Disclosure Tort and the First Amendment: Should the Community Decide Newsworthiness? 64 IOWA L. REV. 185 (1979) (arguing that, as with obscenity, newsworthiness should be decided in accordance with community mores).

54. Ellis, supra note 16 , at 1142 .

55. Wick, supra note 15 , at 424-25. Taken to the extreme, it would also destroy copyright, because the press could always justify the unauthorized reprinting of copyrighted material on the ground that the public was interested in it. See Ellis, supra note 16, at 1142.

56. See David Goldberger, Sources of Judicial Reluctance to Use Psychic Harm as a Basis for Suppressing Racist, Sexist, and Ethnically Offensive Speech, 56 BROOK. L. REV. 1165, 1167 \& n.13 (1991) (noting expansion of First Amendment protection for offensive communications).

57. Howard v. Des Moines Register \& Tribune Co., 283 N.W.2d 289, 302 (Iowa 1979), cert. denied, 445 U.S. 904 (1980).

58. Briscoe v. Reader's Digest Ass'n, 483 P.2d 34, 39-40 (Cal. 1971); see also Melvin v. Reid, 297 P. 91,93 (Cal. Ct. App. 1931). Both cases involved persons who were tried for crimes (Briscoe was convicted) and had their identities revealed years afterwards. Although their names were a matter of public record, the courts reasoned that they had resumed leading "lawful and unexciting" lives, Briscoe, 483 P.2d at 40, and that identification of their names with crime consequently served no public purpose. Id. 
"changed to protect the innocent." turned sharply, and several state and lower federal courts have found the disclosure of names to be newsworthy. ${ }^{60}$

In a series of recent decisions, the United States Supreme Court found that the disclosure of names was protected by the First Amendment and thus did not constitute an impermissible invasion of privacy ${ }^{61}$ However, these cases focused less on the inherent newsworthiness of individuals' names than on the privacy of the facts: in all four cases, the names were already a matter of public record. In the first case, Cox Broadcasting Corp. v. Cohn ${ }^{62}$ a television broadcast mentioned the name of a rape victim. Publicly available court records contained the victim's name, and the court held that "publishing the contents of public records" was outside the reach of privacy actions. ${ }^{63}$ Oklahoma Publishing Co.v. District Court ${ }^{64}$ involved a pretrial order enjoining publication of the name of a juvenile accused of murder. Because the name had already been publicly revealed at the juvenile detention hearings, the Court found no cause of action for invasion of privacy ${ }^{65}$ Similarly, in Smith v. Daily Mail Publishing ${ }^{66}$ which also involved the publication of the identity of an accused juvenile murderer, the Court held the information to be in the public domain, because it had been broadcast previously over police radio. ${ }^{67}$ Most recently, in Florida Star v. B.J.F., ${ }^{68}$ police released the name of a rape victim and a newspaper reprinted the information in violation of a state statute. The Court again held that the government had placed the information "in the public domain" $" 69$ and denied recovery to the plaintiff. 70).

59. To quote the introduction to a once popular television show. Dragnet (NBC Television series, 1967-

60. See, e.g., Ross v. Midwest Communications, Inc., 870 F.2d 271, 274-75 (5th Cir.) (finding rape victim's name was "of unique importance to the credibility and persuasive force of the story" and thus of legitimate public interest), cert. denied, 493 U.S. 935 (1989); Howard v. Des Moines Register \& Tribune Co., 283 N.W.2d at 303 (concluding that name of woman who had been involuntarily sterilized "offered a personalized frame of reference to which the reader could relate, fostering perception and understanding. ... [I]t lent specificity and credibility to the report").

61. See Florida Star v. B.J.F., 491 U.S. 524 (1989); Smith v. Daily Mail Publishing Co., 443 U.S. 97 (1979); Oklahoma Publishing Co. v. District Court, 430 U.S. 308 (1977); Cox Broadcasting Corp. v. Cohn, 420 U.S. 469 (1975).

62. 420 U.S. 469 .

63. Id. at 494.

64. 430 U.S. 308 .

65. Id at 311 .

66. 443 U.S. 97.

67. Id. at 103.

68. 491 U.S. 524.

69. Id. at 538 . 


\section{Sex and Public Disclosure}

As Warren and Brandeis noted over a century ago, ${ }^{70}$ sex and sexuality are considered to reside at the very core of privacy interests. ${ }^{71}$ Perhaps because sex is "a sensitive, key relationship of human existence, central to family life, community welfare, and the development of human personality,"72 people typically are tight-lipped about sexuality, jealously guarding facts concerning their relationships, whether homosexual or heterosexual. ${ }^{73}$ Courts recognize the importance of keeping such information private. ${ }^{74}$ Although many cases have involved the disclosure of sex-related information, only two have specifically considered the privacy of sexuality. We will now consider those cases in turn.

\section{Sipple v. Chronicle Publishing Co. ${ }^{75}$}

In 1975, an ex-Marine named Oliver Sipple foiled an attempt on President Gerald Ford's life by striking the arm of assailant Sara Jane Moore as she was about to fire her gun. ${ }^{76}$ As a result, Sipple became the focus of considerable media attention. ${ }^{77}$ Two days after the assassination attempt, the San Francisco Chronicle published a column revealing Sipple's prominence in the local gay community. Other newspapers quickly followed suit; some papers speculated that President Ford had failed to express his thanks promptly because of Sipple's sexual orientation. ${ }^{78}$ Although open about his homosexuality in San Francisco, frequenting gay bars, marching in gay parades, and associating with leaders of the gay movement, Sipple sued the Chronicle for public disclosure, claiming

70. Warren \& Brandeis, supra note 15, at 216 (listing the "relations of an individual" as one of "the matters of which the publication should be repressed").

71. See, e.g., T. BARTON CARTER ET AL., THE FIRST AMENDMENT AND THE FOURTH ESTATE: THE LAW OF MASS MEDIA 208 (5th ed. 1991) (stating that sexual topics "are generally thought to involve the most intimate matters"); Tom Gerety, Redefining Privacy, 12 HARv. C.R.-C.L. L. REv. 233, 280 (1977) ("By any standard of intuition or analysis, those intimacies begin with the body and its sexuality.").

72. Paris Adult Theatre I v. Slaton, 413 U.S. 49, 63, reh' $g$ denied, 414 U.S. 881 (1973).

73. An unusual propensity to sue over the disclosure of sexual matters demonstrates public reticence about sex. See CARTER, supra note 71, at 208 (noting that most public disclosure cases involve sexual topics); see also Young v. Jackson, 572 So. 2d 378 (Miss. 1990) (involving public disclosure that woman had had hysterectomy); Y.G. v. Jewish Hosp. of St. Louis, 795 S.W.2d 488 (Mo. App. 1990) (involving couple who had been filmed attending hospital program commemorating successful in vitro fertilizations).

74. See Thorne v. City of El Segundo, 726 F.2d 459, 469 (9th Cir. 1983) (finding inquiry into sex life of applicant for police force to be unconstitutional), cert. denied, 469 U.S. 979 (1984); Young v. Jackson, 572 So. $2 \mathrm{~d}$ at 382 ("It requires little awareness of personal prejudice and human nature to know that, generally speaking, no aspect[] of life is more personal and private than those having to do with one's sexual organs and reproductive system."); Y.G. v. Jewish Hosp., 795 S.W.2d at 500 ("[T]he right of privacy has been held to apply particularly to sexual matters or matters of procreation.").

75. 201 Cal. Rptr. 665 (Ct. App. 1984).

76. Jd. at 666 .

77. Id.

78. Id. 
that he had kept his homosexuality private from relatives. ${ }^{79}$ As a result of the disclosure, Sipple claimed, his family had abandoned him, and he had been exposed to "contempt and ridicule causing him great mental anguish, embarrassment and humiliation." ${ }^{80}$ After preliminary discovery, the San Francisco County Superior Court granted summary judgment for the newspaper. ${ }^{81}$

The appellate court upheld the motion for summary judgment on two grounds. ${ }^{82}$ First, the facts disclosed by the Chronicle were not private facts. Sipple's sexual orientation was well known to "hundreds of people in a variety of cities." ${ }^{.83}$ Because information about Sipple's homosexuality was "already in [the] public domain," the articles "did no more than give further publicity to matters which [Sipple] left open to the eye of the public ... ."84 Second, the court held that the facts disclosed were newsworthy, finding that their publication had been prompted by "legitimate political considerations": the desire to combat the stereotype of gays as "timid, weak and unheroic" and to discuss the potential biases of the President. ${ }^{85}$ The court also noted that the publication of Sipple's homosexuality was not "so offensive ... as to shock the community notions of decency." ${ }^{86}$

\section{Diaz v. Oakland Tribune, Inc. ${ }^{87}$}

Diaz v. Oakland Tribune, Inc. involved a newspaper columnist's revelation that Toni Diaz, the first female student body president of a California college, was a transsexual..$^{88}$ Diaz contended that, as a result of the publication, she became depressed and suffered insomnia, nightmares, and memory lapses. ${ }^{89}$ Affirming the lower court's findings, the Diaz court found that because Diaz had kept the sex-change surgery "secret from all but her immediate family and closest friends," her sexual identity was a private fact. ${ }^{90}$ In discussing the newsworthiness of the disclosure, the court emphasized the purpose of First Amendment protection: "[T] keep the public informed so that they may make intelligent decisions on matters important to a self-governing people." Diaz was involved in a public controversy (she had charged the college administration with misuse of student funds), the court found the disclosure of

79. Id. at 667 (Sipple's parents, brothers, and sisters first learned of his homosexuality through the articles.).

80. Id.

81. Id.

82. Id. at 668 .

83. Id. at 669 .

84. Id.

85. Id. at 670 .

86. Id.

87. 188 Cal. Rptr. 762 (Ct. App. 1983).

88. Id. at 765 .

89. Id. at 774 .

90. Id. at 765,771 .

91. Id. at 767 (citing Cox Broadcasting Corp. v. Cohn, 420 U.S. 469, $491-93$ (1975)). 
Diaz's transsexuality to be irrelevant to this matter and thus unnewsworthy. ${ }^{92}$ The court explained that "[t] he fact that she is a transsexual does not adversely reflect on her honesty or judgment. Nor does the fact that she was the first woman student body president, in itself, warrant that her entire private life be open to public inspection." to paint the disclosure as newsworthy by asserting that the article was intended to enlighten the public on "the changing roles of women in society." The "tenor of the article" made clear that the author intended no purpose beyond the stark revelation. ${ }^{95}$

\section{The Relevance of Public Figure Status to the Public Disclosure Tort}

Two distinct types of public figures can be distinguished in the caselaw: limited-purpose public figures and general-purpose public figures. The category of limited-purpose public figures includes people who have voluntarily injected themselves or been drawn into a particular public controversy. ${ }^{96}$ Courts consider limited-purpose public figures to have forfeited their privacy with respect to events that made them famous. ${ }^{97}$ Toni Diaz exemplifies this category. As student body president, she had become "a public figure for some purposes."98 Since her sexuality was not related to her public status, she had not forfeited her sexual privacy. ${ }^{99}$ The category of general-purpose public figures consists of people commonly known as "celebrities."

92. Id. at 773 .

93. Id. (citations omitted).

94. Id.

95. Id. The article stated, in relevant part:

The students at the College of Alameda will be surprised to leam [that] their student body president, Toni Diaz, is no lady, but is in fact a man whose real name is Antonio.

Now I realize, that in these times, such a matter is no big deal, but I suspect his female classmates in P.E. 97 may wish to make other showering arrangements.

Id. at 766. The remainder of the article discussed completely unrelated subjects. See id. at 775-76.

96. See Gertz v. Robert Welch, Inc., 418 U.S. 323, 351 (1974).

97. RESTATEMIENT (SECOND) OF TORTS § 652D cmt. $\mathrm{f}$ (1977).

98. Diaz v. Oakland Tribune, Inc., $188 \mathrm{Cal}$. Rptr. 762, 772-73 (Ct. App. 1983).

99. Id. The columnist who outed Toni Diaz could not claim that his revelation alone made Diaz a public figure for purposes of her sexuality. The Supreme Court has held in the related area of defamation law that such "bootstrapping" is not a defense. Hutchinson v. Proxmire, 443 U.S. 111, 135 (1979) ("[T] hose charged with defamation cannot, by their own conduct, create their own defense by making the claimant a public figure.").

100. See Ann-Margret v. High Soc'y Magazine, Inc., 498 F. Supp. 401,404 (S.D.N.Y. 1980) (asserting that "[t]here is little doubt that [Ann-Margret], who has starred in numerous movies ... . is, as the term has come to be understood, a 'public figure"'). Prosser and Keeton define a public figure as

a person who, by his accomplishments, fame, or mode of living, or by adopting a profession or calling which gives the public a legitimate interest in his doings, his affairs, and his character, has become a 'public personage.' He is, in other words, a celebrity. Obviously to be included in this category are ... an actor, a professional baseball player, a pugilist, or any other entertainer. ... [as well as] public officers, famous inventors and explorers, [and] war heroes .... It includes, in short, anyone who has arrived at a position where public attention is focused upon him as a person.

KEETON ET AL., supra note $27, \$ 117$, at 859-60 (citations omitted). 
stories about general-purpose public figures to be ipso facto newsworthy regardless of their subject matter. Acknowledging broad popular interest in the lives of celebrities, courts have established a "constitutional privilege" to report "facts, events, and information relating to public figures."

While the Restatement suggests that "[t]here may be some intimate details of her life, such as sexual relations, which even the actress is entitled to keep to herself," 102 courts have yet to fulfill the promise of this intuitively appealing dictum. The court in Ann-Margret v. High Society Magazine, Inc. ${ }^{103}$ denied recovery to an actress who had been portrayed nude in a magazine without her consent, in part because the photograph was of "a woman who has occupied the fantasies of many moviegoers" and its publication thus concerned "a matter of great interest to many people." 104 This outcome is typical; though charitable in their rhetoric, courts balk at actually granting recovery. ${ }^{105}$ Many jurisdictions have expressly found that public figures may not maintain a cause of action for comments published about their private lives. ${ }^{106}$

The primary rationale for denying privacy rights to public figures is that, by attaining notoriety, public figures have consented to publicity and thus waived their right to privacy. ${ }^{107}$ This argument does not fare well under scrutiny. In situations involving private figures, three criteria must be met to support a finding of implied assumption of risk: the conduct must manifest consent, the risk must be encountered voluntarily, and the risk must be encountered with full knowledge and appreciation. ${ }^{108}$

Traditionally, consent to waive rights must be at least clearly implied in conduct. ${ }^{109}$ For example, consenting to be photographed might constitute a relinquishment of rights to sue following publication of that photograph. ${ }^{110}$

101. Campbell v. Seabury Press, 614 F.2d 395, 397 (5th Cir. 1980). The Second Circuit abserved, "[r] egrettably or not, the misfortunes and frailties of . . . 'public figures' are subjects of considerable interest and discussion to the rest of the population." Sidis v. F-R Publishing Corp., 113 F.2d 806, 809 (2d Cir.), cert. denied, 311 U.S. 711 (1940).

102. RESTATEMENT (SECOND) OF TORTS $\S 652 \mathrm{D}$, cmt. h (1977).

103. 498 F. Supp. 401 (S.D.N.Y. 1980).

104. Id. at 405 .

105. See, e.g., Time, Inc. v. Hill, 385 U.S. 374, 383 n.7 (1967) ("This limitation to newsworthy persons and events does not of course foreclose... [the recovery of] damages where [r]evelations may be so intimate and unwarranted in view of the victim's position as to outrage the community's notions of decency.") (citation omitted); Sidis, 113 F.2d at 809; Ann-Margret, 498 F. Supp. at 404 ("It is clear that a public figure does not, simply by virtue of his or her notoriety', lose all rights to privacy."). In each of these cases, the plaintiff was denied recovery.

106. See 1 SLADE R. METCALF, RIGHTS AND LIABILITIES OF PUBLISHERS, BROADCASTERS AND REPORTERS $\$ 2.22$ (1982).

107. This claim is comparable to the "assumption of risk" argument for public figures in defamation jurisprudence. Here, however, the greater ability of public figures to rebut comments is not implicated because, by hypothesis, the facts disclosed are true. See Katz, supra note 44, at 830; Melville B. Nimmer, The Right to Speak from Times to Time: First Amendment Theory Applied to Libel and Misapplied to Privacy, 56 CAL. L. REV. 935, 961 (1968).

108. KEETON ET AL., supra note $27, \S 68$, at $484-92$.

109. Id. at $484-86$.

110. See, e.g., Cox v. Hatch, 761 P.2d 556, 563 (Utah 1988) ("While a person may have a legitimate interest in protecting his or her identity from exploitation by others, that interest is minimal when the person 
Conduct in excess of that consented to is not protected. ${ }^{111}$ Thus, explicit consent to publication in one medium (say, books) may not be a defense against an action stemming from publication in another medium (say, newspapers). ${ }^{112}$ Giving an interview may not necessarily imply consenting to be named in print. ${ }^{113}$ Clearly, judicial ideas of what constitutes "consent" change drastically when publication involves public figures.

Volition is also frequently missing in cases in which courts deny recovery. A person does not consent to intrusive publicity merely by graduating from college at the age of sixteen ${ }^{114}$ or by being born to famous parents. ${ }^{115}$ To recover under the public disclosure tort, the publication must be "highly offensive" and unreasonable; ${ }^{116}$ it seems fanciful to suggest that even a public figure would voluntarily and knowingly consent to such publicity. A hypothetical Dominican baseball player who, because of his talent, is brought up to the American major leagues has not voluntarily forfeited all rights regarding his personal life in the same way that, for example, Mick Jagger (who clearly cultivates notoriety) has. Courts have, on occasion, implicitly recognized parties' intent not to waive important privacy interests, especially in situations involving sexual intimacy. ${ }^{117}$

Under general tort principles, knowledge of a general risk may not suffice for a finding of waiver; courts often require knowledge of the specific risk that caused the plaintiff's harm. ${ }^{118}$ The knowledge requirement should frustrate a finding of waiver in a case involving sex-related disclosures. It is doubtful that many celebrities knowingly assumed this unusual risk. While our hypothetical baseball player may have assumed the general risk that his inability to hit curve balls or his mercurial temper in the dugout would become legitimate topics of some public interest, it is less likely he considered the specific risk of having his sexual proclivities announced to the world.

allows his picture to be taken in a public or semi-public place....").

11. See, e.g., Crump v. Beckley Newspapers, Inc., 320 S.E.2d 70, 84 (W.Va. 1984).

112. See McCabe v. Village Voice, Inc., S50 F. Supp. 525, 527, $529-30$ (E.D. Pa. 1982) (holding that, although plaintiff consented to be photographed by photographer who said that "he wanted to publish a book," that consent did not extend to publication of photograph in weekly newspaper).

113. Hawkins v. Multimedia, Inc., 344 S.E.2d 145, 146 (S.C. 1986) (holding that, while plaintiff spoke knowing that reporter was writing an article on teenage pregnancy, plaintiff did not consent to being identified), cert. denied, 479 U.S. 1012 (1986).

114. Sidis v. F-R Publishing Corp., 113 F.2d 806, 807 (2d Cir.), cert denied, 311 U.S. 711 (1940).

115. Meeropol v. Nizer, 560 F.2d 1061, 1066 (2d Cir. 1977) (finding that children of Rosenbergs are public figures because of their parents' highly-publicized trial for divulging atomic secrets), cert. denied, 434 U.S. 1013 (1978).

116. RESTATEMENT (SECOND) OF TORTS § 652D, cmt. c (1977).

117. Gerety, supra note 71 , at $295 \mathrm{n} .215$ (concluding that Supreme Court's reluctance to find plaintiff a public figure in Time, Inc. v. Firestone, 424 U.S. 448 (1976), "derives from the legitimate concern that as to sexual intimacy at least none of the parties in fact intended to waive their rights to privacy").

118. KEETON ET AL., supra note $27, \S 68$, at 487 . For example, a person at a hockey game may have assumed the risk of known dangers, such as being hit by a puck, but not assumed the risk of unknown dangers, such as being hit by a runaway Zamboni. 
The inappropriateness of the doctrine of implied assumption of risk to public figures has led some to conclude that this concept is more accurately termed "constructive waiver." It is merely a way of restating the conclusion that First Amendment considerations trump any privacy rights claimed by public figures. ${ }^{119}$

\section{Resuscitating the PUBlic Disclosure TORT: THE IMPLICATIONS OF OUTING}

The right to privacy is in danger of becoming -and indeed may have already become-a right surviving only in dicta. ${ }^{120}$ Recent jurisprudence and critical commentary have irrevocably and unconditionally subordinated the right to privacy to the First Amendment. ${ }^{121}$ The outing of prominent homosexuals presents a situation in which common law privacy rights clash directly with the constitutional right to free speech and a free press. Critics of outing bemoan the fact that the public disclosure tort is so anaemic that "it probably would offer no protection against so egregious an intrusion as outing."122

Commentators and jurists afford privacy so little weight because they misunderstand its importance. ${ }^{123}$ Many assume, as Prosser seemingly did, that public disclosure of private information implicates only minor, common law rights against the infliction of psychological distress. ${ }^{124}$ Properly viewed,

119. See Edward J. Bloustein, Privacy, Tort Law, and the Constitution: Is Warren and Brandeis' Tort Petty and Unconstitutional as Well?, 46 TEX. L. REV. 611, 627 (1968); Peter L. Felcher and Edward L. Rubin, Privacy, Publicity, and the Portrayal of Real People by the Media, 88 YALE L.J. 1577, 1587 (1979).

It seems unfair to say public figures have forfeited their right to privacy. Notoriety is frequently an unintended, if not unwelcome, byproduct of their efforts. Talented people will be discouraged from the full use of their talents if they are rewarded by microscopic scrutiny of their personal lives. Persons entering fields which expose them to the public eye must consider the loss of virtually all claims and expectations of privacy in calculating the costs of such a move. Respect for privacy would lower these costs. Ruth Gavison, Privacy and the Limits of Law, 89 YALE L.J. 421, 456 (1980).

120. See, e.g., Florida Star v. B.J.F., 491 U.S. 524, 533 (1989) (noting that privacy rights are "plainly rooted in the traditions and significant concems of our society"). Justice Stevens recognized in Supreme Court jurisprudence a constitutionally endowed "zone of privacy" that involves "the individual interest in avoiding disclosure of personal matters ...." Whalen v. Roe, 429 U.S. 589, 598-99 (1977). See also Virgil v. Time, Inc., 527 F.2d 1122, 1128 n.8 (9th Cir. 1975), cert. denied, 425 U.S. 998 (1976) (quoting Rosenblatt v. Baer, 383 U.S. 75, 92 (1966) (Stewart, J., concurring)) (stating that privacy "reflects no more than our basic concept of the essential dignity and worth of every human being-a concept at the root of any decent system of ordered liberty").

121. See supra text accompanying notes 56-69. Justice White has observed that "the trend in 'modern' jurisprudence has been to eclipse an individual's right to maintain private any truthful information that the press wished to publish." Florida Star v. B.J.F., 491 U.S. at 553 (White, J., dissenting). See generally Diane L. Zimmerman, Requiem for a Heavyweight: $A$ Farewell to Warren and Brandeis's Privacy Tort, 68 CORNELL L. REV. 291 (1983) (arguing, inter alia, that public disclosure tort is moribund and should be abandoned).

122. Wick, supra note 15 , at 433 .

123. Judge Bazelon wrote, "Perhaps privacy is not given the recognition it deserves as a fundamental value simply because the concept is so difficult to formulate or justify in nonsubjective terms." David $\mathrm{L}$. Bazelon, Probing Privacy, 12 GoNz. L. REV. 587, 588 (1977). This is because "[u]ntil very recently, discussions of privacy did not often indulge in the typically humbling and menial task of definition." Gerety, supra note 71 , at 237.

124. Bloustein, supra note 15 , at 1004 . 
however, the public disclosure tort implicates basic values of our constitutional system.

\section{A. Interest in Inviolate Personality}

To be sure, public disclosure of private facts can result in severe psychic distress, stemming from the nature of the revelation itself. By laying intimate information open to public view, public disclosure assaults a person's individuality. ${ }^{125}$ The victim is outraged and mortified by having the public know her most intimate secrets, ${ }^{126}$ and is robbed of the prerogative of making the disclosure herself, thus losing control over her own life and identity. ${ }^{127}$ The violation of privacy is, essentially, a blow to human dignity or an injury to individuality. ${ }^{128}$ The world is a witness, a peeping Tom, to the victim's intimate life. ${ }^{129}$ Psychological studies indicate that the coming-out process is painful even when voluntarily undertaken. ${ }^{130}$ Though the psychological ramifications of outing remain "largely unstudied,"131 it stands to reason that forced disclosure would be far more traumatic.

State ${ }^{132}$ and federal ${ }^{133}$ legislatures, recognizing the importance of informational privacy, have enacted a multitude of provisions that forbid the disclosure of private information by the government. Congress has recognized a fundamental constitutional right to informational privacy. ${ }^{134}$ Courts have zealously protected private information from government disclosure, ${ }^{135}$ holding official

125. Id. at 981.

126. Id.; Bloustein, supra note 119 , at 619 .

127. Seth F. Kreimer, Sunlight, Secrets, and Scarlet Letters: The Tension Between Privacy and Disclosure in Constitutional Law, 140 U. PA. L. REv. 1, 71 (1991).

128. Bloustein, supra note 15 , at 973 .

129. Id. at 979.

130. Harold P. Martin, M.D., The Coming-Out Process for Homosexuals, 42 HoSP. \& COMMUNITY PSYCHIATRY 158 (1991).

131. Erik F. Strommen, "You're a What?": Family Member Reaction to the Disclosure of Homosexuality, J. HoMOSEXUALTTY, Vol. 18, Nos. 1/2, at 37, 54 (1989) (noting how little is known about ramifications of discovery of homosexuality by family members).

132. See, e.g., ALASKA CONST. art. I, $\$ 22$ ("The right of the people to privacy is recognized and shall not be infringed."); CAL. CNV. CODE $\$ 1798.1$ (West 1992) ("[A]ll individuals have a right of privacy in information pertaining to them."); HAWAII CONST. art. I, § 6; MONT. CONST. art. II, § 10.

133. See Don R. Pember, The Burgeoning Scope of "Access Privacy" and the Portent for a Free Press, 64 IOWA L. REv. 1155, 1180 (1979). Certain provisions of the General Education Provisions Act, 20 U.S.C. \$ $1232 \mathrm{~g}(\mathrm{~b})(4)$ (1988), the Privacy Act of 1974, 5 U.S.C. \& 552a (1988), and the Freedom of Information Act, 5 U.S.C. $\$ 552(b)(6)(1988)$ can be used to restrict access to information in the government's control.

134. "The Congress finds that ... the right to privacy is a personal and fundamental right protected by the Constitution of the United States." Congressional Findings and Statement of Purpose, Privacy Act of 1974, Pub. L. No. 93-579, § 2(a)(4), codified at 5 U.S.C. § 552a (1988).

135. See, e.g., United States Dep't of Justice v. Reporters Comm. for Freedom of the Press, 489 U.S. 749 (1989) (upholding nonselease of information under Freedom of Information Act exception); ACLU of Mississippi v. Mississippi, 911 F.2d 1066 (5th Cir.) (vacating lower court's order to disclose records conceming state agency's efforts to maintain racial segregation because individual privacy rights were not adequately considered), reh'g denied, 919 F.2d 735 (1990). 
action to implicate constitutional values. ${ }^{136}$ While outings of prominent homosexuals do not involve state action and thus do not implicate the Fourth Amendment, they nevertheless involve violations of the same, weighty interests, "values . . . similar to those involved in battery, assault, and false imprisonment cases": ${ }^{137}$ the interest in preserving individual dignity against unreasonable intrusions. ${ }^{138}$

\section{B. Free Speech Interests}

Although privacy is generally held to conflict with free speech, it actually helps promote familiar First Amendment values. Privacy shields the individual from "pressures to conform, ridicule, punishment," and other forms of societal interference. ${ }^{139}$ By providing a refuge, privacy enables individuals to deliberate in solitude, develop opinions, form groups, and thereby acquire the strength to dissent publicly. ${ }^{140}$ Privacy is thus essential to democratic government, fostering moral autonomy and promoting the formation and dissemination of unorthodox views. ${ }^{141}$ In NAACP v. Alabama, ${ }^{142}$ the Supreme Court held that the Due Process Clause of the Fourteenth Amendment, which embraces the freedoms of association and speech, prohibited the state-compelled disclosure of NAACP members' names because such a revelation would have an adverse affect on the group's ability to promote its platform. ${ }^{143}$ The Court reasoned, "[i]nviolability of privacy in group association may in many circumstances be indispensable to preservation of freedom of association, particularly where a group espouses dissident beliefs." ${ }^{\text {"144 }}$ While outing does not implicate the First

136. See, e.g., Fraternal Order of Police, Lodge No. 5 v. Phila, 812 F.2d 105, 115 (3d Cir. 1987) (holding that "financial information ...., albeit less intimate than medical information, is entitled to privacy protection"); DeMasi v. Weiss, 669 F.2d 114, 119, 121 (3d Cir. 1982) (noting that "[i]t can scarcely be denied that the public exposure of one's wallet or purse is ... an invasion of privacy" and that government disclosure of financial matters "may well implicate constitutional rights").

137. Bloustein, supra note 15 , at 1005.

138. Id. at 994-95. The current conception of the Fourth Amendment is more privacy-based than propertybased. Compare Katz v. United States, 389 U.S. 347, 353 (1967) (finding that Fourth Amendment protects "people ... not simply 'areas") and Warden, Maryland Penitentiary v. Hayden, 387 U.S. 294, 304 (1967) (stating that "the principal object of the Fourth Amendment is the protection of privacy rather than property . . . .") with Olmstead v. United States, 277 U.S. 438, 457-66 (1928) (finding wiretaps not covered by Fourth Amendment because they did not involve actual physical invasion).

139. Gavison, supra note 119 , at 448 .

140. Id. at 450 .

141. Id. at 455; Randall P. Bezanson, Public Disclosures as News: Injunctive Relief and Newsworthiness in Privacy Actions Involving the Press, 64 IOWA L. REV. 1061, 1077 (1979); Kreimer, supra note 127, at 67.

142. 357 U.S. 449 (1958).

143. Id. at 460,463 . Under current Supreme Court jurisprudence, the right of association is protected by the First Amendment, made applicable to the States by the Fourteenth Amendment. See Democratic Party v. Wisconsin, 450 U.S. 107, 121 (1981).

144. NAACP v. Alabama, 357 U.S. at 462. See generally THE CONSTITUTION OF THE UNITED STATES OF AMERICA: ANALYSIS AND INTERPRETATION, 1036-44 (1987) (discussing development and current interpretation of right of association). 
Amendment where government action is not involved, the injured interests are similar.

Outing uniquely illustrates the value of privacy in promoting sexual autonomy and how the absence of privacy protection can chill free discussion. The gay rights movement formed and gained strength in underground meetings; ${ }^{145}$ social pressures to conform would have -made it impossible to do so in the open. Homosexuality is strongly condemned ${ }^{146}$ and severely penalized $^{147}$ in our society. This is reflected in the fact that the false imputation of homosexuality is considered defamatory in the vast majority of states. ${ }^{148}$ Homosexuals are also frequently the target of hate crimes. ${ }^{149}$ The pervasive

145. D'EMILIO \& FREEDMAN, supra note 1, at 319; D.J. WEST, HOMOSEXUALITY RE-EXAMDNED 143 (1977). One of the first homosexual organizations in the United States, the Mattachine Society, took its name from the court jester who spoke truth while hiding behind a mask. Founded in 1950, it "dropped the mask" of privacy in 1954, incorporated, and began publicly providing a number of services to the gay community. Id. at 143-44.

146. The percentage of Americans who believe that homosexual sex is "always wrong" has varied between 70 and 75\% since 1980. RICHARD A. POSNER, SEX AND REASON 64 (1992). Studies indicate that one-third of Americans surveyed have less favorable attitudes toward lesbians and gay men as a result of the AIDS epidemic. EDITORS OF THE HARVARD LAW REVIEW, SEXUAL ORIENTATION AND THE LAW 8 \& n.60 (1990) [hereinafter SEXUAL ORIENTATION AND THE LAW]; see also Gregory M. Herek, Myths About Sexual Orientation: A Lawyer's Guide to Social Science Research, 1 L. \& SEXUALTTY 133, 165 (1991).

147. In a recent survey, nearly one-fifth of gay men reported that they had lost jobs or been denied employment because they were gay. SEXUAL ORIENTATION AND THE LAW, supra note 146, at 65; see also Rowland v. Mad River Local Sch. Dist., 730 F.2d 444 (6th Cir. 1984) (holding that school board could dismiss bisexual teacher after she revealed her sexual orientation to fellow staff, despite jury finding that her revelation did not interfere with school operations), cert. denied, 470 U.S. 1009 (1985); Gaylord v. Tacoma Sch. Dist. No. 10,559 P.2d 1340 (Wash.) (upholding school board decision to presume a homosexual teacher "immoral" and thus unfit to teach), cert. denied, 434 U.S. 879 (1977). Gay men and lesbians can be denied entry to the United States because of their sexual preference. SEXUAL ORIENTATION AND THE LAW, supra note 146, at 151-52. See generally Rhonda R. Rivera, Our Straight-Laced Judges: The Legal Position of Homosexual Persons in the United States, 30 HASTINGS L.J. 799 (1979).

Even outing advocates admit that the imputation of homosexuality can have a lasting impact on a person's reputation and career. Activist Michelangelo Signorile concedes, "I can't say no one's career will be hurt. In every movement, there's bound to be some discomfort." Broeske \& Wilson, supra note 11, at F90. One actor worries, "[homosexuality] freaks the audience out. ... This thing can completely destroy careers." Id. at F6. For example, CBS cancelled actor Jim Nabors' variety show after rumors spread that he was gay. Carla Hall, Encounters With a Man of Mystery, WASH. POST, July 23, 1986, at C2.

148. See, e.g., Mazart v. State, 441 N.Y.S.2d 600 (Ct. Cl. 1981) (holding that publication by student newspaper of letter indicating claimants were gay was libel per se); Buck v. Savage, 323 S.W.2d 363, 369 (Tex. Civ. App. 1959) (holding that calling a man "queer" was defamatory because it imputed criminal conduct, sodomy). In upholding a judicial finding that the imputation of homosexuality is defamatory, a New York court concluded that:

It cannot be said that social opprobrium of homosexuality does not remain with us today. Rightly or wrongly, many individuals still view homosexuality as immoral. Legal sanctions imposed upon homosexuals in areas ranging from immigration to military service have recently been reaffirmed despite the concurring Judge's observation in Watkins that it “demonstrates a callous disregard for the progress American law and society have made toward acknowledging that an individual's choice of life style is not the concern of government, but a fundamental aspect of personal liberty." ... [D]espite the fact that an increasing number of homosexuals are publicly expressing satisfaction and even pride in their status, the potential and probable harm of a false charge of homosexuality, in terms of social and economic impact, cannot be ignored. Matherson v. Marchello, 473 N.Y.S.2d 998, 1005 (App. Div. 1984) (citations omitted).

149. According to a recent study commissioned by the National Institute for Justice, homosexuals are victimized more often than any other minority group. SEXUAL ORIENTATION AND THE LAW, supra note 146, at 31 . One in five gay men, and one in ten lesbians reported being physically assaulted, according to another study. Id.; Herek, supra note 146, at 166. The incidence of such hate crimes has increased as a result of 
disapproval of homosexuality makes social pressures to conform especially high; without a viable right of informational privacy, the danger of stultifying free thought is great. ${ }^{150}$ The Supreme Court could have been describing a homosexual rights group when it wrote:

Petitioner has made an uncontroverted showing that on past occasions revelation of the identity of its rank-and-file members has exposed these members to economic reprisal, loss of employment, threat of physical coercion, and other manifestations of public hostility. Under these circumstances, we think it apparent that compelled disclosure of [group] membership is likely to affect adversely the [group's] ability ... to foster beliefs which they admittedly have the right to advocate, in that it may induce members to withdraw . . . and dissuade others from joining it because of fear of exposure .... and of the consequences of this exposure. ${ }^{151}$

Now, as in the heyday of McCarthyism, ${ }^{152}$ exposure as a homosexual can effectively silence a person, subjecting him to ridicule and depriving him of political and social associations fundamental to free speech interests. The fear of exposure that outing engenders may cause many homosexuals to modify their conduct and alter their associations in order to avoid detection. ${ }^{153}$ Furthermore, mass disclosures that can seriously impair political rights-such as disclosure of membership rosters in Alabama in the 1950's or the publication of gay students' names today ${ }^{154}$ - differ only in scope ${ }^{155}$ from individual outings.

Proponents of outing argue that if the liberty from constraining social norms that is promoted by privacy is desirable, it is even more desirable to attack those norms directly. Privacy, they argue, perpetuates the very problems it purports to ease, reducing surface tensions while simultaneously maintaining the stigma of homosexuality. Outing makes the public aware of the contributions of homosexuals to society, promoting tolerance by heterosexuals and openness among closet gays. Outing advocates have argued that, while sex itself is private, sexual preference is not; because heterosexuality is not a private fact, homo-

the AIDS epidemic. SEXUAL ORIENTATION AND THE LAW, supra note 146, at 31. See also People v. Nitz, 572 N.E.2d 895 (IIl.) (involving gruesome bias murder of a homosexual), cert. denied, 112 S. Ct. 344 (1991).

150. Kreimer, supra note 127, at 70 \& n.194 ("[T] he pressure of visibility begins to reorganize behavior at its source, shaping it in conformity with the normative standards of the observer.") (quoting Harvard behavioralist Professor Shoshana Zuboff).

151. NAACP v. Alabama, 357 U.S. $449,462-63$ (1958).

152. D'EMILIO \& FREEDMAN, supra note 1, at 292-94.

153. It is conceivable that the outing of Pete Williams affected the ability of closeted homosexuals at the Department of Defense to meet and associate, causing them to modify their behavior in order to avoid detection in this notoriously homophobic institution.

154. See supra note 2 .

155. Outers will surely assert that they would not perpetrate mass outings. However, British gays in 1991 announced that they would expose hundreds of closet homosexuals in Parliament, in the courts, and in the Church. Neil McKenna, Outing's Bitter Truths, THE INDEPENDENT (LONDON), July 29, 1991, at 17. The threat dissolved in the face of possible legal action. See British News in Brief, FACTS ON FILE WORLD NEWS DIGEST, Aug. 8, 1991, at 601. 
sexuality should not be either. ${ }^{156}$ To hold otherwise would be to perpetuate the popular impression that homosexuality is immoral or unnatural. ${ }^{157}$

But this argument is disingenuous. First, homosexuality is not just like heterosexuality; if it were, there would be no "closets" and everyone would be "out." The continuing societal stigmatization of homosexuality ${ }^{158}$ is what motivates outing. Secondly, it is difficult to change positive morality. Even after thirty years of civil rights legislation, racism pervades our society. Although no studies have been conducted to determine how outing affects public views of homosexuality, anecdotal evidence indicates that outing is no panacea. As one lesbian wryly put it, "I'm still waiting for the news of Malcolm Forbes's homosexuality to improve the quality of my life."159 Under present circumstances, public disclosure can destroy lives while accruing only marginal gains for gay rights. The only lasting effect is the burden on the target. ${ }^{160}$

Moreover, depriving outing targets of a tort remedy is an inappropriate and inefficient mechanism for changing public attitudes towards homosexuality. The role of tort law is to make the injured whole, not to change social mores. Judges have long recognized this truth in the field of defamation law, and thus "take the world as [they] find it," even if those who would think less of the injured party could be characterized as "wrong-thinking."161 Attitudes are best changed in other ways, such as the enactment of antidiscrimination legislation, which would improve the everyday lives of homosexuals in a systematic way. ${ }^{162}$

Proponents of outing must recognize that all they offer is a "quick fix," drawing attention to the cause of homosexuals for a few days or weeks. The price exacted for outing is great. Outing erodes the privacy that was instrumental in the formation of the gay rights movement, ${ }^{163}$ and which allows most gays

156. Signorile, Yale Law School Address, supra note 6.

157. Ruth Harlow, American Civil Liberties Union Lesbian \& Gay Rights Project, Address at Yale Law School Symposium, Outing: The Debate Over Forcing Lesbian and Gay Public Figures Out of the Closet (Dec. 4, 1991) [hereinafter Harlow, Yale Law School Address].

158. See supra notes 146-148.

159. Heller, supra note 5 , at 13 (quoting Cindy Carr, an anti-outing journalist at the Village Voice). In an interview last year, two outing practitioners (Mike Carson of ACT-UP New York and Bill Dobbs of Queer Nation) could not point to any concrete political or social gains resulting from their activities. See Charles Laurence, After the Stars Went Out, DallY TELEGRAPH, July 30, 1991, at 15. The public may perceive outing as punishment, reinforcing the notion that homosexuality is shameful. Tim McFeeley, Director, Human Rights Campaign Fund, Address at Yale Law School Symposium, Outing: The Debate Over Forcing Lesbian and Gay Public Figures Out of the Closet (Dec. 4, 1991).

160. See Bezanson, supra note 141 , at 1102 .

161. Thus, for years courts considered the imputation of illegitimacy or rape defamatory, despite the fact that allowing recovery perpetuated "wrong-thinking" social stigmas. CARTER, supra note 71, at 79-80; KEETON ET AL., supra note $27, \$ 111$, at $777-78$.

162. Califomia Govemor Pete Wilson recently signed into law a bill that "prohibit[s] discrimination ... in any aspect of employment . . . based on actual or perceived sexual orientation." 1992 Cal. Legis. Serv. 915 (West); see also Jane Gross, In Reversal, California Governor Signs a Bill Extending Gay Rights, N.Y. TMIES, Sept. 26, 1992, at 1. A few days earlier, the Kentucky Supreme Court struck down that state's sodomy law, holding that the statute violated the state constitutional right to privacy and the right to equal treatment under the law. See Kentucky v. Wasson, No. 90-SC-558-TG, 1992 WL 235412 (Ky. Sept. 24, 1992).

163. See supra note 145 and accompanying text. 
the autonomy to "come out" on their own timetable and of their own volition..$^{164}$ Outing thus could potentially damage the cause of gay rights more than it helps. In most areas of the country, outside of major cities and certain progressive enclaves, revelation of a person's homosexuality could effectively disband inchoate gay organizations. Outing a prominent gay banker in (say) Omaha may make Nebraskans aware of gays in their midst, but at the cost of destroying a network of associations built around him. ${ }^{165}$ Finally, by chipping away at privacy rights, gay activists may cause setbacks in other areas in which they still desire privacy, such as in mandatory AIDS testing and reporting.

\section{OUTING AND THE FIRST AMENDMENT}

The First Amendment is couched in absolutist language: "Congress shall make no law ...." Despite this sweeping admonition, the Supreme Court has "long recognized that not all speech is of equal First Amendment importance"166 and that speech can be regulated consistent with the First Amendment. For example, speech may be regulated as to "time, place, and manner."167 Some types of speech may be accorded reduced protection, notably commercial speech ${ }^{168}$ and defamatory speech. ${ }^{169}$ The Court has held that some types of speech-obscene speech, "fighting words," and child pornography-merit little or no First Amendment protection. ${ }^{170}$ Thus, in practice, First Amendment interests are not absolute, but must be weighed against competing concerns. This Part attempts to determine whether outing speech can be restricted in a manner consistent with First Amendment protections.

164. According to a national study, the average amount of time elapsed between when a person realized he was gay and when he came out was 4.6 years. This length of time underlines the pressures gays feel to conform. See Herek, supra note 146, at 146 (reporting survey of 113 lesbians and 287 gay men).

165. Some outing advocates purport only to out those persons who are prominent and powerful enough that harm done to the target will be minimal. See Signorile, Yale Law School Address, supra note 6; Harlow, Yale Law School Address, supra note 157. However, the assurances of a handful of practitioners is no guarantee against what thousands of other activists might do.

166. Dun \& Bradstreet, Inc. v. Greenmoss Builders, Inc., 472 U.S. 749, 758 (1985).

167. See, e.g., Ward v. Rock Against Racism, 491 U.S. 781, 791, reh'g denied, 492 U.S. 937 (1989).

168. See Virginia State Bd. of Pharmacy v. Virginia Citizens Consumer Council, Inc., 425 U.S. 748, 758 (1976).

169. See, e.g., New York Times v. Sullivan, 376 U.S. 254 (1964).

170. See Chaplinsky v. New Hampshire, 315 U.S. 568, 571-72 (1942) ("There are certain well-defined and narrowly limited classes of speech, the prevention and punishment of which have never been thought to raise any Constitutional problem. These include the lewd and obscene, the profane, the libelous, and... 'fighting' words-those which by their very utterance inflict injury or tend to incite an immediate breach of the peace."). The Court has retreated from this statement in RA.V. v. City of St. Paul, Minnesota, 112 S. Ct. 2538, 2543-45 (1992), holding that these classes of speech are entitled to some minimal First Amendment protection. 


\section{A. The Purpose of First Amendment Protection}

The central importance of speech on public issues, or "matters of public concern," is long-established in First Amendment doctrine. ${ }^{171}$ Since New York Times v. Sullivan, ${ }^{172}$ the Supreme Court has placed speech regarding matters of public concern squarely "at the heart of the First Amendment's protections," "173 and "on the highest rung of the hierarchy of First Amendment values." ${ }^{174}$ Such speech is of preeminent value because it transcends mere selfexpression. Freedom of expression concerning public questions "assure[s] unfettered interchange of ideas for the bringing about of political and social changes desired by the people,"175 and thus is "the essence of self-government." 176 The Court has found speech to merit full First Amendment protection when it meets either the "status" test or the "content" test. ${ }^{177}$ The "status" test determines whether the subject of the speech is a public official ${ }^{178}$ or figure. ${ }^{179}$ Speech concerning private figures is accorded lesser First Amendment protection. ${ }^{180}$ The "content" test is met when the speech at issue is of public concern. ${ }^{181}$

Supreme Court doctrine thus accords with the predominant scholarly theory of the First Amendment, associated with Alexander Meiklejohn. ${ }^{182}$ This theory views speech as valuable principally because it is instrumental to democratic government. Although this "instrumentalist" formulation of the First Amendment has been caricatured as involving only explicitly political speech, in fact it encompasses a broad range of expression, from purely political writings to

171. See R.A.V., 112 S. Ct. at 2563-65 (Stevens, J., concurring).

172. 376 U.S. 254 (1964).

173. First Nat'l Bank v. Bellotti, 435 U.S. 765, 776, reh'g denied, 438 U.S. 907 (1978).

174. Carey v. Brown, 447 U.S. 455,467 (1980). (1957)).

175. New York Times v. Sullivan, 376 U.S. at 269 (quoting Roth v. United States, 354 U.S. 476, 484

176. Garrison v. Louisiana, 379 U.S. 64, 75 (1964).

177. See Philadelphia Newspapers, Inc. v. Hepps, 475 U.S. 767, 775 (1986) ("One can discern ... two forces that may reshape the common-law landscape to conform to the First Amendment. The first is whether the plaintiff is a public official or figure, or is instead a private figure. The second is whether the speech at issue is of public concern.").

178. New York Times v. Sullivan, 376 U.S. at $279-80$.

179. Curtis Publishing Co. v. Butts, 388 U.S. 130, reh'g denied, 389 U.S. 889 (1967).

180. See Gertz v. Robert Welch, Inc., 418 U.S. 323 (1974).

181. Dun \& Bradstreet, Inc. v. Greenmoss Builders, Inc., 472 U.S. 749, 763 (1985) (holding that libelous speech not regarding a matter of public concern enjoys no special constitutional immunity); Connick v. Myers, 461 U.S. 138, 148 (1983) (suggesting that speech of public employees is protected if it is determined to relate to "matters of 'public concern"). Contrary to the popular view that content-based regulation of speech is per se unconstitutional, the Supreme Court has noted that the content of speech can determine the level of protection it is afforded. See, e.g., R.A.V. v. City of St. Paul, Minnesota, 112 S. Ct. 2538, 2545-47 (1992). As Justice Stevens commented, "much of our First Amendment jurisprudence is premised on the assumption that content makes a difference." Id. at 2563 (Stevens, J., concurring).

182. See, e.g., ALEXANDER MEIKLEJOKN, FREE SPEECH AND ITS RELATION TO SELF-GOVERNMENT 22-27 (1948). Most critics of the Meiklejohn view concede the special importance of speech on public interests. Professors Jackson and Jeffries observe, "the fighting issue is not the validity of Meiklejohn's insight but rather its exclusivity." Thomas H. Jackson and John C. Jeffries, Jr., Commercial Speech: Economic Due Process and the First Amendment, 65 VA. L. REV. 1, 11 (1979). 
creative literary works. ${ }^{183}$ To serve the ends of democratic government, "[f]reedom of discussion ... must embrace all issues about which information is needed or appropriate to enable the members of society to cope with the exigencies of their period." 184 This model provides the philosophical framework for a hierarchical theory of speech. It extends maximum protection to matters of clear relevance to self-government and lesser protection to matters of little significance in the resolution of public controversies.

Outing practitioners themselves draw lines between different types of outing. Two distinct varieties emerge, although there is some overlap. The first type of outing-so-called "gratuitous" outing - merely identifies an individual as gay, and does not attempt to imbue this fact with greater significance or relate it to some greater controversy. ${ }^{185}$ The outings of Malcolm Forbes ${ }^{186}$ and Toni Diaz $^{187}$ are paradigmatic: the articles that outed them conveyed little more than simple allegations about these individuals' sexuality. The second type of outing discloses a person's sexuality in the context of a controversy in which he is involved, and is termed "political" outing. The outings of Pete Williams ${ }^{188}$ and Oliver Sipple ${ }^{189}$ fall into this category.

The "content" test has been rendered all but irrelevant by the "status" test, because courts assume that any statement made regarding a celebrity is of public interest. ${ }^{190}$ Two general arguments are advanced for the proposition that statements about the sexual preference of celebrities are inherently newsworthy. First, some argue that any statement made about a celebrity is, ipso facto, of public interest. A second argument is that outing a celebrity creates a role model for gays and an ambassador to straights, and thus engenders debate on public issues. These arguments will be addressed in turn.

183. Felcher \& Rubin, supra note 119, at 1597. Speech performs two basic functions in this model. The first is to maintain the integrity of democratic self-government. Any speech which contributes to public debate on political or social issues receives full First Amendment protection under this theory. The second function is to communicate and develop culture. Id. Creative, expressive speech such as literature and dance would thus come within the scope of constitutional protection. Id. at 1598.

184. Thornhill v. Alabama, 310 U.S. 88, 102 (1940) (Murphy, J.).

185. See Laurence, supra note 159 (distinguishing between "gratuitous" and "political" outing); see also Signorile, Yale Law School Address, supra note 6 (distinguishing between "active" and "passive" outing).

186. See Broeske \& Wilson, supra note 11, at F6. Signorile, who "outed" Forbes, did so for three stated reasons: (1) to set the history books straight, (2) to let the public know that "we [homosexuals] are everywhere" and (3) to persuade gays to come out. Heller, supra note 5, at 12. The fact that Forbes was dead releases OutWeek of any potential liability stemming from the incident, because privacy rights are generally believed to expire with a person. RESTATEMENT (SECOND) OF TORTS $\S 652$ I (1977).

187. See supra text accompanying notes 87-95. Although Diaz involved a transsexual rather than a homosexual, the parallel is close enough to be enlightening.

188. See supra note 4 .

189. See supra text accompanying notes $75-86$.

190. See supra note 101 and accompanying text. 


\section{B. Status: Is a Celebrity's Sexual Preference Inherently Newsworthy?}

If there is a zone of privacy around the intimate details of even famous individuals' lives, as the Supreme Court consistently has suggested in dicta, ${ }^{191}$ sexual orientation, as the most private of facts, ${ }^{192}$ must fall within that zone. Sexual orientation is distinct from conduct. ${ }^{193}$ Whatever the "cause" of sexual preference, sexuality inheres in the psyche, and need never be manifested in a way that is visible to the public eye. ${ }^{194}$ Perhaps for these reasons, one federal court held disclosure of one's own sexual preference was not a matter of public concern for First Amendment purposes within the context of employment. ${ }^{195}$

The intimacy of the facts involved suggests that even celebrities should be considered private figures with regard to their sexuality. Giving a celebrity private status for this one subject would require that an outing meet the content test-that it be relevant to a matter of public concern-in order to come within the scope of the First Amendment's protection. There is precedent for this proposal in Supreme Court jurisprudence. In the defamation case Time, Inc. $v$. Firestone,${ }^{196}$ the Supreme Court held that the former wife of a wealthy industrialist, manifestly a "celebrity,"197 had not forfeited her status as a private figure with regard to her divorce. The Court based its conclusion on three factors. First, Mary Alice Firestone had not voluntarily entered into the divorce proceedings, and thus had not voluntarily assumed the risk of this publicity. ${ }^{198}$ Second, Firestone had not assumed a position of "special prominence in the resolution of public questions," 199 and thus did not come within the sweep of the "status" test. Third, the Court observed, disclosing the details of many courtroom battles "would add almost nothing toward advancing ... uninhibited debate on public issues"200 and thus would not meet the requirements of the "content" test. The Court implicitly rejected the "leave it to the press" model

191. See supra note 120; see also Diaz v. Oakland Tribune, 188 Cal. Rptr. 762, 773 (Ct. App. 1983) ("Public figures more celebrated than [Diaz] are entitled to keep some information of their ... sexual relations private.").

192. See supra notes $70-74$ and accompanying text.

193. See Grant, supra note 15 , at 107.

194. Id.; Herek, supra note 146 , at 150-51 (describing biological, psychological, and social theories of sexual preference).

195. Rowland v. Mad River Local Sch. Dist., 730 F.2d 444, 449 (6th Cir. 1984) (employee discharged as consequence of revealing bisexuality to coworkers; such speech is not protected by First Amendment), cert. denied, 470 U.S. 1009 (1985).

196. 424 U.S. 448 (1976).

197. Although the Court found her not to be a public figure for purposes of reporting on her divorce, it is hard to avoid the conclusion that Mary Alice Firestone was a "celebrity" or "public figure" for purposes of privacy. She was married to "the scion of one of America's wealthier industrial families"; her divorce was covered in Time magazine; and the Court conceded that her divorce was "of interest to some portion of the reading public." Id. at 450,454 . See KEETON ET AL., supra note $27, \S 117$, at 860 .

198. 424 U.S. at 454.

199. Id. at 454-55 (citation omitted).

200. Id. at 457. 
of newsworthiness, ${ }^{201}$ stating that to find the divorce proceedings of the wealthy a "public controversy" for First Amendment purposes would "equate 'public controversy' with all controversies of interest to the public."202

Firestone seems to stand for the proposition that, as to intimate matters, celebrities are private figures. First, by finding that Mary Alice Firestone had not assumed the risk of publicity arising from her divorce, ${ }^{203}$ the decision supports the argument that waiver of privacy rights must be full, knowing, and voluntary, even in cases involving public figures. ${ }^{204}$ Second, Firestone indicates that a person becomes a public figure only with respect to matters in which he has assumed special prominence. This rule parallels the Restatement test, which holds that "[s]ome reasonable proportion" must be maintained "between the event or activity that makes the individual a public figure and the private facts to which publicity is given." ${ }^{205}$ Under the Firestone analysis, a gay celebrity would thus retain privacy rights regarding his sexuality unless he made a full, knowing and voluntary waiver of them, or unless his sexuality somehow became relevant to some larger controversy.

\section{Content: Is Sexual Preference Newsworthy in Context?}

\section{Gratuitous Outing: The "Role Model" Rationale}

Advocates contend that each prominent homosexual outed serves as a role model for other gays and as an ambassador to straights. As one commentator has noted, "the very presence of prejudice" that makes outing so painful makes an individual's sexual preference "a valuable subject of media coverage"; outing a gay celebrity "takes the debate out of the abstract and onto a level with which the general public can identify."206 Facts regarding a celebrity's sexuality are thus relevant to the structuring of society, and therefore have some value as speech. The Sipple court found this justification compelling enough to grant such a disclosure First Amendment protection. ${ }^{207}$

This rationale does not fare well under closer scrutiny. Role model outing violates the principle that the private facts disclosed should be relevant to what makes the individual a public figure. ${ }^{208}$ One recent role model outing involved a prominent record-industry businessman, David Geffen. ${ }^{209}$ Geffen's sexual

201. See supra text accompanying notes 54-55 and Zimmerman, supra note 121 , at $353-55$, for a discussion of the "leave it to the press" model of newsworthiness.

202. 424 U.S. at 454.

203. Id.

204. See supra text accompanying notes 108-119.

205. RESTATEMENT (SECOND) OF TORTS $§ 652 D \mathrm{cmt}$. h (1977).

206. Wick, supra note 15 , at 432 .

207. Sipple v. Chronicle Publishing Co., 201 Cal. Rptr. 665, 670 (Ct. App. 1984).

208. See supra note 205 and accompanying text.

209. Activists outed Geffen in 1991, ostensibly to provide a role model to gays in the record industry. Heller, supra note 5, at 13; Signorile, Yale Law School Address, supra note 6. 
orientation had no discernible impact on his performance as President of Geffen Records. If his sexuality is relevant to public debate, it is relevant only to the general, sociological issue of the role of gays in society.

Competing interests clearly outweigh the limited benefits of role model outing. Even under the best of circumstances, the relationship between outing a particular figure and effecting a societal change is simply too attenuated ${ }^{210}$ to override the outing target's privacy rights. Two courts have weighed the equities in related public disclosure cases and found that mere relevance to broad societal goals did not justify disclosure of private facts. ${ }^{211}$ Furthermore, the role model rationale is unprincipled and liable to abuse. If gays need role models, so does every other troubled minority, such as AIDS patients, rape victims, and victims of child abuse.

\section{Political Outing}

Some commentators assert that a person's sexual preference is so private that any disclosure should be actionable, and suggest extending absolute privacy protection to all "the inner workings of a person's mind."212 Under this proposed regime, even political figures would possess an extensive zone of privacy, because their private sexual orientation would only be of public concern "in so far as [it is] acted upon."213

Such blanket prohibitions on disclosure cannot be justified. Although disclosure of a person's sexual preference is a grave invasion of privacy, there are circumstances when sexual preference is relevant to self-government. For example, a closeted government official who made disparaging public remarks about homosexuals or who enforced discriminatory programs might be a valid target for outing. ${ }^{214}$ Her hypocrisy calls into question her honesty and

210. See supra note 159 and accompanying text. Weighed against hypothetical benefits are very real harms. See supra notes 146-155 and accompanying text.

211. Ross v. Midwest Communications, Inc., 870 F.2d 271 (5th Cir.), cert. denied, 493 U.S. 935 (1989), involved a television documentary that questioned the guilt of a man convicted of rape. The court found that specific facts, including defendant's name, were relevant to a matter of public concem because they were "uniquely crucial" to revisiting the question of guilt; however, the court acknowledged that "the rape victim's name may be irrelevant when ... the publisher's 'public concern' goes to a general, sociological issue." Id. at 275. In Diaz v. Oakland Tribune, Inc., 188 Cal. Rptr. 762 (Ct. App. 1983), the court rejected defendant's attempts to relate the disclosure of plaintiff's transsexuality to the "contemporary social issue" of "the changing roles of women in society." Id. at 773.

212. See, e.g., Grant, supra note 15 , at 139.

213. Id. at n.261. Polls reflect popular support for such a position. A recent poll conducted by Time magazine and the Cable News Network found that $72 \%$ of Americans believed outing to be wrong. Time/CNN: Opposition to Ban of Gays from Military, Outing, THE HOTLINE, Aug. 6, 1991, available in LEXIS, Nexis Library, Wires File.

214. As Congressman Bamey Frank has said, "you cannot try to make sodomy illegal and then commit sodomy yourself." Laurence, supra note 159 , at 15 . 
motivation, and thus information about her sexuality is relevant to the question of her fitness for office. ${ }^{215}$

Pete Williams, 1991's most prominent outing target, served as a spokesman for the Pentagon. Though he was not personally responsible for the military's longstanding policy of excluding gays from the armed services, statements regarding his alleged sexual preference deserved full First Amendment protection for several reasons. First, such claims (which concededly may or may not be true) purported to call into question the character of a high public official who helped implement a rule forbidding activities which he allegedly practiced. Second, this claim was uniquely relevant to the broader question of gays in the military. By alleging that a high official in the Department of Defense was homosexual, the outers directly attacked one of the traditional rationales for excluding gays from the military-that gays present a security risk. ${ }^{216}$ By seeking to demonstrate that a gay upper-echelon official posed no threat to security, the outers may have helped remove one stone from the wall that officially excludes gays from the military. Months after the outing, Secretary of Defense Cheney repudiated the security rationale as "an old chestnut."217

Granting full First Amendment protection is less clearly warranted when a public official's sexual preference has not affected her actions, and her campaign for office has done nothing to make her sexuality an issue. As George Will has griped, the question "'Are [these charges] relevant?' is as important as 'Are they true?"'218 In such cases, the outing may have been merely "morbid and sensational prying" and thus not a matter of public concern. Conversely, events can make a person's sexual preference newsworthy even when he is not a government official and has not acted hypocritically. The Sipple case exemplifies this. Sipple's sexuality became relevant (arguably) because it shed light on President Ford's attitude towards gays. ${ }^{219}$ Because the information potentially revealed the President's prejudices, its disclosure could be constitutionally protected as relevant to the public decision of who should govern. ${ }^{220}$

Public figures are at times as politically influential as government officials. Roy Cohn was a prominent American lawyer who was active in politics and a sidekick to Senator McCarthy. Terry Dolan was a conservative Republican

215. The Supreme Court has recognized that

society's interest in the officers of government is not strictly limited to the formal discharge of official duties.... [T] he public's interest extends to "anything which might touch on an official's fitness for office ... . . Few personal attributes are more germane to fitness for office than dishonesty, malfeasance, or improper motivation, even though these characteristics may also affect the official's private character."

Gertz v. Robert Welch, Inc., 418 U.S. 323, 344-45 (1974) (citation omitted).

216. D'EMIIIO \& FREEDMAN, supra note 1, at 292.

217. Barton Gellman, Cheney Rejects Idea That Gays Are Security Risk, WASH. POST, Aug. 1, 1991, at A33; Maria Puente, Bill would bar gay GIs' discharge, USA TODAY, May 19, 1992, at 4A.

218. Will, supra note 10.

219. See supra text accompanying note 85 .

220. See David A. Logan, Tort Law and the Central Meaning of the First Amendment, S1 U. PIT. L. REV. 493, 558 (1990). 
fundraiser who died of AIDS. Both were publicly anti-gay; both are reputed to have led active lives as homosexuals. ${ }^{221}$ Both had access to real political power despite their nominally private status. As political figures, they were accountable to the public for their honesty and motivation. By playing a significant role in the resolution of public questions, they made their sexual preference newsworthy.

The question becomes much more difficult with high-profile public figures, such as actors and actresses. ${ }^{222}$ Some outing advocates argue that Hollywood is much more important than Washington, D.C. in shaping attitudes. They argue that actors who glamorize heterosexuality or vilify homosexuality are even more dangerous than their political kin. ${ }^{223}$ Telling the world that a major heartthrob is homosexual may shape public views about how "normal" homosexuality is, and therefore may affect public views about the regulation of homosexual activity. However, cases such as Ross $v$. Midwest Communications ${ }^{224}$ suggest that, to be newsworthy, disclosure of homosexuality must bear direct relevance to matters of public concern to come within the ambit of full First Amendment protection. ${ }^{225}$ Outing as practiced by tabloids, ${ }^{226}$ which make no pretense of imbuing such facts with political content, thus is mere "morbid and sensational prying."

\section{CONCLUSION}

The outing controversy involves a direct clash between competing values - the First Amendment and the common law right of privacy. When full First Amendment protection is implicated, it dominates the hierarchy of rights, and outing speech must be protected at the expense of privacy rights. However, not all speech is of equal First Amendment value. When speech implicates less

221. See Mira Friedlander, Being Pulled Out of the Closet, ToRonTo STAR, Sept. 3, 1991, at B1 (discussing Cohn); Out with "Outing", NEwSDAY, May 29, 1990, at 42 (discussing Dolan).

222. Professor Frederick Schauer has argued persuasively that the "public figure" category of Supreme Court defamation jurisprudence is overbroad and that defamatory commentary on such figures does not merit blanket application of the Times $v$. Sullivan actual malice standard applied to public officials. Frederick Schauer, Public Figures, 25 WM. \& MARY L. REv. 905 (1984). Professor Schauer notes that the archetype cases used in formulating the "public figure" test (Butts and Walker) both involved powerful individuals in their respective communities who had placed themselves squarely at the heart of a controversy of great public interest. Unwisely generalizing from these two cases, the Supreme Court concluded that public officials and public figures wield approximately equivalent influence in the resolution of government affairs. Id. at 915-16. Schauer argues that, had the archetype cases involved more typical facts, the Court would not have accorded statements regarding all public figures equal First Amendment protection, because for many public figures, exerting even an indirect influence on public policy is "aberrational." Id. at 917.

223. Signorile believes that famous actors like Rock Hudson glamorize heterosexuality. Signorile, Yale Law School Address, supra note 6. Activists pointed fingers at Jodie Foster because she appeared in the film, The Silence of the Lambs, which some said portrayed homosexuals in a bad light. See Heller, supra note 5 , at 12 .

224. 870 F.2d 271 (5th Cir.), cert. denied, 493 U.S. 935 (1989).

225. Id. at 275 .

226. The Globe's story on Lyle Alzado is a good example of this genre. See supra note 14. 
than full First Amendment protection, it can be regulated to advance a compelling state interest-in this case, the protection of privacy rights.

Current law favors First Amendment interests to the virtual exclusion of privacy rights, treating celebrities as public figures even for purposes of their sexuality. This balance of constitutional and common law rights is erroneous. Because it need never be manifested publicly, sexual preference is not inherently newsworthy. The disclosure of a person's sexual preference is therefore of lesser First Amendment value unless it is relevant to a "matter of public concern." When activists out a prominent figure to provide a positive example of homosexuals - so-called "role model" outing-information about his sexuality is relevant only to the general, sociological issue of the role of gays in society. In such cases, the privacy interest is at its apex while the interest in disclosure is at its nadir. ${ }^{227}$ The compelling state interests advanced by privacy rights should therefore prevail.

Though sexuality need not be public, it can become so under certain circumstances. Officials may make their sexuality relevant to a public controversy (by being hypocritical), and private citizens may be thrust into the public eye in such a way as to make their sexuality relevant (as in the case of Oliver Sipple). Outings performed to accomplish immediate political objectives-socalled "political" outings-are directly relevant to governance and thus deserve full First Amendment protection.

Examination of the two types of outing speech-role model outing and political outing - suggests that Supreme Court jurisprudence is inadequate to balance competing First Amendment and privacy interests in outing cases. Current law emphasizes the status of the subject, rather than the content of the disclosure. The foregoing analysis of outing suggests that this emphasis is backwards. Status is not relevant for determining the constitutional protection of outing speech because, as Time v. Firestone ${ }^{228}$ suggests, all persons, famous and obscure, are private figures for purposes of their sexuality. Instead, the appropriate inquiry is the content test, which determines whether the individual's sexual orientation is relevant to a public controversy. Judicial implementation of revised standards would not be overly onerous: despite predictions of doom from academic writers, the courts have shown some facility in making distinctions between public matters and private matters. Removing the distraction of the status test may make the determination easier.

227. Cf. United States Dep't of Justice v. Reporters Comm. for Freedom of the Press, 489 U.S. 749, 780 (1989) (discussing privacy interests in maintaining confidentiality of arrest records).

228. 424 U.S. 448 (1976). 